\title{
Response
}

\section{JAMES KENNEDY}

I very much appreciate the time taken by the two reviewers, Bob Moore and Anjana Singh, to read and comment upon A Concise History of the Netherlands. ${ }^{1}$ More than other types of books, an introductory and comprehensive text like this is difficult to critique. It cannot chiefly consist of a specialist's insight, coming from roughly the same field, into the work of another specialist. Reviewers have to reflect on the wider purposes and reasons for such a 'concise history', and I know that this is a challenge.

Moreover, the task is made perhaps more difficult by the fact that there are no footnotes, which is a standard characteristic of the Cambridge University Press ‘Concise Histories' series. There is indeed, as Singh notes, no bibliography as such (in contrast to the Dutch version of the book, where Dutch-language works predominate). There is, though, a fifteenpage section for 'further reading', which offers interested readers a guide for English-language works on the history of the country and which must function as a bibliography. Under these conditions, it cannot be surprising that the very text of the book is defined by the existing historiography. As a writer, I admittedly found it liberating to write 'off-piste', without having to encapsulate many tiresome summaries of historiographical discussions (although at various points I do expressly allude to them). But if the approach leaves me freer to address issues I find important, it probably made it harder for reviewers to offering an easy critique to any of the choices I made - why some emphases and not others?

As Moore rightly notes, A Concise History of the Netherlands attempts to be as kaleidoscopic as possible, shifting between different kinds of history (social, political etc.) while continually making judgments about what the educated reader really ought to know about the history of the Netherlands. But as I indicate in my introduction, I do make choices in it. I try to deprivilege Holland and Amsterdam (an endeavor which in hindsight I find largely successful but not as thoroughgoing as I wanted). Additionally, 
the Netherlands is systematically compared with other countries precisely so as to contextualize Dutch unicity and more often to undermine claims of exceptionalism. Napoleon's 1810 annexation of the Netherlands, for example, was not unique and not solely grounded in his impatience with his brother Louis. I am sensitive to Bob Moore's criticism that I did not place the Dutch experience during the Second World War in a systematic comparative perspective, but I do emphasize at one point that Nazi aims for the Netherlands led to a particularly deadly effect for the country's Jews, compared to Belgium or Denmark. The history also pays attention to the geopolitical position of the Netherlands among the great powers, which is often and surprisingly glossed over by other historians. Unlike any other history of the Dutch kingdom, my book also tries to integrate the history of the Dutch Caribbean into a wider national history. In all of these respects I try to break out of the mould of pure national history.

The structure of A Concise History is essentially political, revealing my affinities for political history, though I am delighted that a reader like Moore finds that I give considerable attention to economics, which I certainly tried to do. In addition to that, as some other readers have rightly noted, $A$ Concise History gives special attention not only to the religious dimensions but to the ethical and moral issues in Dutch society as well, often absent or neglected in other histories. Having reflected further, I would say now that my history focuses less on the everyday lives of the Dutch (though there is some of that) and more, to put it broadly, on the public sphere. In a parallel way, an emphasis on the political and economic means that A Concise History offers less cultural history, admittedly a focus point of much of the best recent historiography. I don't think you should go to my book if you want to find out a great deal about art or literature, points of attention to which Piet Rietbergen in his own survey gives attention. One can't do everything.

Moore and Singh each take up a major theme and each is particularly worthy of reflection and response. The first I shall take up is Moore's suggestion that 'the premise behind the book is essentially teleological and that the writing concentrates on the features of history that have some relevance to the current political, social and economic structure of the Kingdom of the Netherlands as it is today'. As Moore himself notes, that is not necessarily wrong for a book (like this one) that is intended as an introduction to Dutch history. But what does it mean for a historical work to be teleological and what are the problems with it?

I raise this question because it is a criticism of this book that I have occasionally heard from my fellow historians in the Netherlands. National histories, I will admit, are notoriously teleological, drawing straight lines from the past into the present, classically as a vindication of the nation-state. 


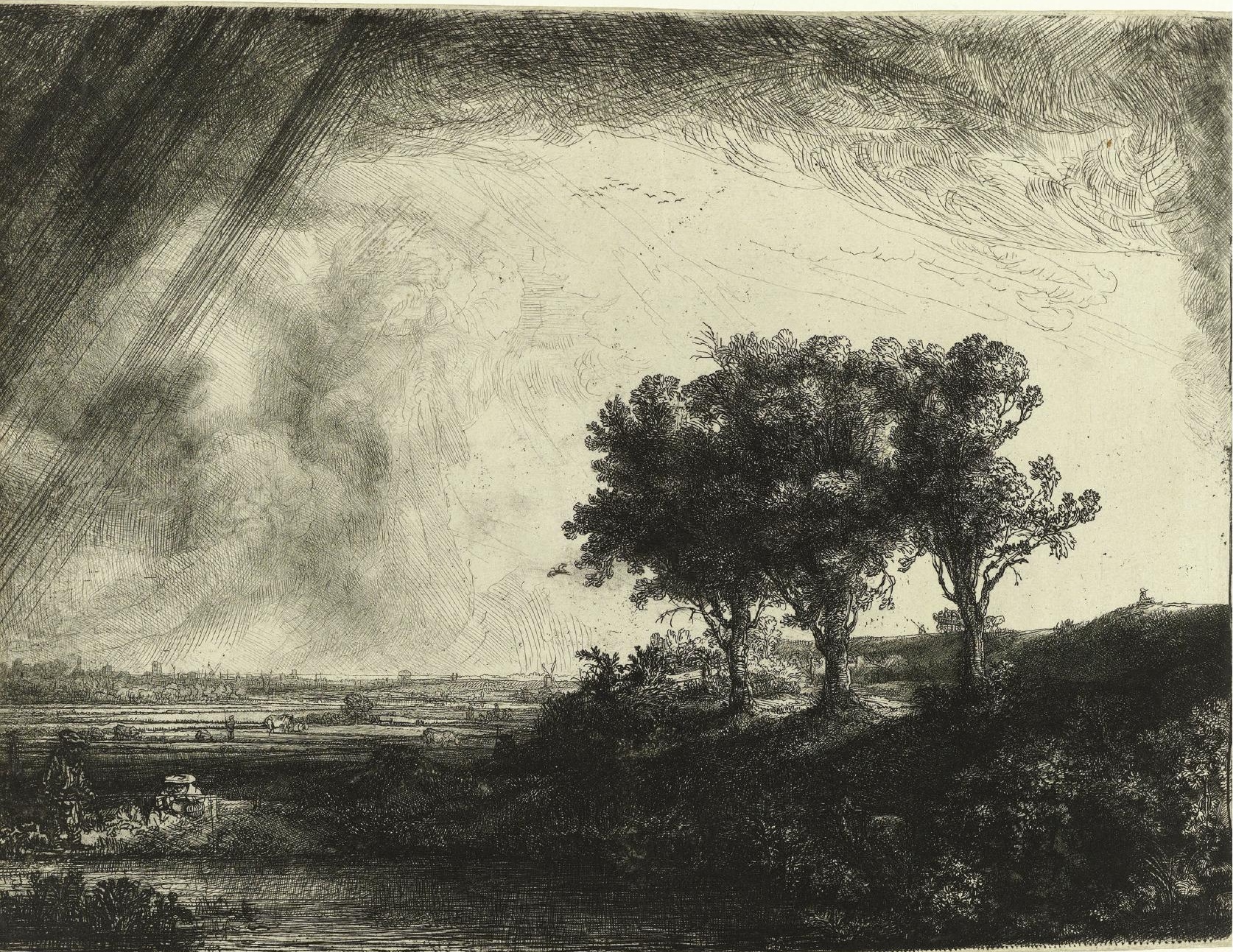

$\Delta$

De drie bomen (The three trees), Etching Rembrandt van Rijn, 1643 Rijksmuseum Amsterdam. 
For this reason, many historians, certainly in the Netherlands, have become particularly suspicious of national narratives that suppose some national essence developing over the ages.

I, too, was eager to avoid such a pitfall. In fact, the conclusion - where I most explicitly see the current-day Netherlands in terms of two persistent themes (a recurring capacity for adaptability and the necessity of learning to live together) was not in the initial manuscript at all. In the submitted work, I simply ended it at the beginning of 2016, and nothing more. Cambridge University Press' anonymous reviewer didn't like this very much. The reviewer thought this too abrupt an ending and suggested that I develop a 'short, thoughtful conclusion' that articulates 'thematic continuities' that I wished to impress upon readers.

This advice was right. Part of the problem of not having a conclusion is compositional; it is simply not a very satisfying to end a book without any reflection about what one has written in the last four hundred pages. But there are other issues too at stake, the chief one being the 'so what?' question. So why write a national history like a Concise History of the Netherlands in the first place?

That answer is not as self-evident as it once was. Strongly influenced by post-national sentiments, Dutch historians, those of the Golden Age excepted who bask in the interest of their international colleagues, tend to think of the history of their own little country as not very compelling to others. Historians (or potentially interested readers) from abroad with little knowledge of the Netherlands, also may need to be convinced. It is easy to ignore unobtrusive little countries like the Netherlands which was, and in some ways still is, a larger player in world affairs than is generally known. A necessary counterpunch to this dismissive stance requires an author to argue that Dutch history is more than of antiquarian interest, that it matters more than we might suppose, that what the Dutch have often painfully put together has had historical consequences that continues to this very day. And I would furthermore argue that it matters in the deepest sense not because the Dutch are wholly unique - much of what happened here also happened elsewherebut because their successes and their foibles are part of a wider human story. $\mathrm{I}$, in fact, say as much in the introduction to the book. National histories ought to avoid seeing the past as wholly unique or the present as essentially inevitable. This Concise History goes out of its way to avoid both pitfalls.

That also means that one must have a keen eye for the contradictions and ironies of patterns in Dutch history, even if one thinks, as I do, that current Dutch society in many ways (certainly not all) promotes human flourishing. Moore rightly points out that Dutch adaptability - in my view a persistent feature of Dutch society - did not work out so well during the Second World War, when the non-Jewish Dutch live-and-let-live attitude toward Nazi rule had catastrophic effects for their Jewish fellow citizens. The chief point of the conclusion, I would emphasize, is to underscore that 
the Dutch society's propensity toward adaptability and tolerance shifted constantly over time, and that these propensities did not impact everyone positively.

The second issue, raised by Singh, is the place of the colonial in A Concise History. The guidelines for writing the book stipulated that I confine myself to the territory that is presently part of the Netherlands (or, as I interpreted it, the Kingdom of the Netherlands so as to include the six Caribbean islands). I could have been much more rigorous about keeping the colonial out, but I did not think that tenable or fruitful, and tried to trace at least the most important contours of the Dutch colonial legacy, which Singh also notes. But that is admittedly an approach that is only going to go so far. I make multiple references to Dutch atrocities in the Indies in the course of several centuries, but this hardly scratches, of course, the surface of the violence and of the wars that involved the Dutch in one way or another in their colonial misadventures. Similarly, the racist and discriminatory nature of Dutch colonialism receives some mention, though perhaps not enough. At no point, though, did I attempt to cast Dutch colonial policy in positive terms; even my reference to Dutch Ethical Policy, mentioned by Singh in this context, was an attempt to understand its purpose as the Dutch saw it, not as it ought to be seen.

This does not mean that my approach could not benefit from improvement. If I wanted to better show the colonial impact on Dutch history, then I think the best way would not be to spend more time outlining the many Dutch colonial excesses in former colonies, but to focus on how the colonial legacy impacted life within what is now the Netherlands. I make several references to the wealth gained from the colonies, but I could have given more structured attention to the ways in which everyday life was influenced by the colonial exchange: consumption, employment and migration, to name sectors from a now emerging historiography.

As a concluding thought, Moore's and Singh's comments might be brought together in what Singh has called 'lessons learned' from Dutch history. A Concise History is, in the last analysis, an upbeat book, insofar as it esteems the Dutch for showing adaptability and a live-and-let-live stance over the course of a long period of time, even as my book is at pains to recognize the tawdry and painful sides of Dutch history. On that side of the ledger I viewed Dutch colonial history. But perhaps that is not the whole story. The Netherlands' colonial legacy is still with us. That means that just having a critical view of the Dutch colonial past - which I have attempted to do - is not enough. 'Lessons learned' also means paying closer attention to present voices from that past, and how that might alter our current discussions. How to do that more effectively will be one of the chief tasks of any revised edition. 
James Kennedy (1963) is Dean of University College Utrecht (UCU) and Professor of Modern Dutch History at Utrecht University. His expertise is postwar history, in the first instance of the Netherlands but also with an eye to transnational and comparative perspectives. The general focus is on the intersection of political, social and cultural history of this period, with a particular interest in the ethical dimensions of policy and its relationship to society. This has translated into books and grants into the following themes: the cultural change of 'the Sixties', the history of euthanasia, changes in civil society and citizenship, anticorruption strategies, church-state relations and the history of drugs policy. Email: J.C.Kennedy@uu.nl. 